\title{
Successful Spermatogonial Stem Cells Transplantation within Pleuronectiformes: First Breakthrough at inter-family Level in Marine Fish
}

\author{
Li Zhou ${ }^{1,2,3^{*}}$, Xueying Wang ${ }^{1,2^{\star}}$, Qinghua Liu ${ }^{1,2}{ }^{\bowtie}$, Jingkun Yang1, Shihong $\mathrm{Xu}^{1,2}$, Zhihao $\mathrm{Wu}^{1}$, Yanfeng \\ Wang ${ }^{1,2}$, Feng You ${ }^{1}$, Zongcheng Song ${ }^{4}$ and Jun $\mathrm{Li}^{1,2}{ }^{\circledR}$ \\ 1. The Key Laboratory of Experimental Marine Biology, Center for Ocean Mega-Science, Institute of Oceanology, Chinese Academy of Sciences, Qingdao, \\ China. \\ 2. Laboratory for Marine Biology and Biotechnology, Qingdao National Laboratory for Marine Science and Technology, Qingdao, China \\ 3. College of Life Science, Ningde Normal University, Engineering Research Center of Mindong Aquatic Product Deep-Processing, Fujian Province University, \\ Ningde, China. \\ 4. Weihai Shenghang Aquatic Product Science and Technology Co. Ltd., Weihai, China. \\ *These authors contributed equally to this work. \\ $\square$ Corresponding authors: Qinghua Liu, E-mail: qinghualiu@qdio.ac.cn, Tel: +86 532 82898716; Jun Li, E-mail: junli@qdio.ac.cn, Tel: +86 53282898718.
}

(C) The author(s). This is an open access article distributed under the terms of the Creative Commons Attribution License (https://creativecommons.org/licenses/by/4.0/). See http://ivyspring.com/terms for full terms and conditions.

Received: 2021.05.28; Accepted: 2021.10.06; Published: 2021.10.25

\begin{abstract}
As a promising biotechnology, fish germ cell transplantation shows potentials in conservation germplasm resource, propagation of elite species, and generation of transgenic individuals. In this study, we successfully transplanted the Japanese flounder ( $P$. olivaceus), summer flounder ( $P$. dentatus), and turbot (S. maximus) spermatogonia into triploid Japanese flounder larvae, and achieved high transplantation efficiency of $100 \%, 75-95 \%$ and $33-50 \%$ by fluorescence tracking and molecular analysis, respectively. Eventually, donor-derived spermatozoa produced offspring by artificial insemination. We only found male and intersex chimeras in inter-family transplantations, while male and female chimeras in both intra-species and intra-genus transplantations. Moreover, the intersex chimeras could mature and produce turbot functional spermatozoa. We firstly realized inter-family transplantation in marine fish species. These results demonstrated successful spermatogonial stem cells transplantation within Pleuronectiformes, suggesting the germ cells migration, incorporation and maturation within order were conserved across a wide range of teleost species.
\end{abstract}

Key words: Pleuronectiformes; germ cell transplantation; spermatogonia; triploid recipient; inter-family

\section{Introduction}

Germline stem cells have multiple differentiation potential [1]. They are transplanted into allogeneic or xenogeneic recipients, and then colonize, differentiate, mature and finally produce donorderived gametes, which is called germ cell transplantation technology (GCT). GCT is a promising biotechnology for protecting endangered species as well as long-term preserving genetic resources by cryopreserved germ cells transplantation [2-4]. In addition, through this technology, economic fish with long breeding cycle, large body size and low fertility can be produced by using small fish agent that is easy to raise and reproduce, which can save labor and breeding costs [5, 6]. It can also apply to sex control, such as producing YY supermales without administering exogenous sex steroids [7]. This surrogate broodstock technology will open up a new way for fish breeding, genetic improvement, and conservation and efficient utilization of germplasm resources.

This technology originated from the 1990s, it has been greatly developed in fish in recent years [8-12]. Initially, GFP-labelled PGCs of rainbow trout $(O$. mykiss) were transplanted into the peritoneal cavity of the allogeneic or closely related xenogeneic species such as masu salmon (O. masou) at hatchling stage, 
resulting in production donor-derived gametes $[9,13]$. Currently, GCT has been carried out in many families, including Cyprinid [14, 15], Adrianichthyidae [16, 17], Tetraodontidae [18], Sciaenidae [12, 19], Carangidae $[5,20]$. Different stem germ cells including primordial germ cells (PGCs), spermatogonia, and oogonia were used as donor cells being transplanted into embryos, hatchlings and adults [20-22]. Because of the limited number of PGCs from embryos, spermatogonia were usually used as donor cells for its sexual bipotency and large amounts [23-26]. Therefore, spermatogonia were used for transplantation in more and more fish species instead of PGCs, especially for several marine fish species $[19,27,28]$. For example, jack mackerel ( $T$. japonicus) successfully produced functional gametes of Japanese yellowtail (S. quinqueradiata) by intraperitoneally transplanting spermatogonia [6].

Recipient preparation is of prime importance for the successful transplantation of spermatogonial stem cells. Optimal recipient can greatly improve the efficiency of transplantation without immunological rejection of endogenous germ cells [29-31]. Sterile hybrid [32], triploid [33] or recipients with germ cell depletion induced by dead end-knockdown (dnd-MO) [34] or busulfan treatment [35] are commonly used for transplantation. However, not every type of sterility is easy to be obtained and applied to all species. The sterility by $d n d-\mathrm{MO}$ is just limited to model organisms, which is difficult to obtain for economic species [10], while busulfan treatment drastically disturbs the testicular microenvironment leading to the low efficiency, and only applies to the adult recipient producing unidirectional gamete $[35,36]$. Another type of sterility is hybrid, but whether the hybrid is sterile or not depends on the combination of the parental crosses, in which only a part of species can be obtained viable and sterile hybrids [37]. In contrast, the triploids seem like an optimal recipient, and has been successfully used in intra- or inter-species transplantations such as rainbow trout [2, 33], Grass Puffer (T. niphoblesparents) [18], Niber croaker (N. mitsukurii) [12].

Turbot (S. maximus, genus Scophthalmus, family Scophthalmidae), Japanese flounder ( $P$. olivaceus, genus Paralichthys, family Paralichthyidae) and summer flounder ( $P$. dentatus, genus Paralichthys, family Paralichthyidae), which belong to Pleuronectiformes, are economically important marine flatfish species for aquaculture. However, since turbot and summer flounder were introduced into China, for the long-term culture and inbreeding, the germplasm resources have gradually degraded and turbot cannot spawn naturally [38-40]. In previous study of flatfish, testicular germ cells of Senegalese sole (S. senegalensis) were transplanted into turbot larvae, and only detected proliferation in turbot juveniles, without continuous monitoring of donor cells development in the recipient [41]. Therefore, it is necessary to explore the possibility of GCT for germplasm resources protection and surrogate broodstock among these species. In the present study, we aimed to investigate GCT within Pleuronectiformes at species, genus, and family levels. We isolated the cryopreserved spermatogonia from Japanese flounder, summer flounder, and turbot whole testes, then labeled and intraperitoneally transplanted into triploid Japanese flounder larvae, and detected the entire development process of donor-derived cells in the recipients by fluorescence tracing and molecular analysis. Finally, we successfully obtained donor-derived functional spermatozoa and offspring by artificial insemination.

\section{Materials and Methods}

\section{Experimental animals and general rearing protocols}

All experiments were performed in accordance with the relevant national and international guidelines and approved by the Institutional Animal Care and Use Committee, Institute of Oceanology, Chinese Academy of Sciences.

In this study, all the fish were reared at Shenghang Sci-Tech Co., Ltd. (Weihai, Shandong Province, China). For donor preparation, sexually mature male individuals (about $3 \mathrm{Y}$ ) were cultured in $30 \mathrm{~m}^{3}$ circular tanks with flowing seawater, and fed with frozen fish. For recipient preparation, the Japanese flounder broodstock was raised in a circular tank, and the breeding conditions were the same as the above donors. The method of getting triploid Japanese flounder referred to the previous description [42]. Freshly ovulated eggs and milts were collected from broodstock. The semi-dry method was used for artificial insemination according to the ratio of milts and eggs 1:100. Then, the fertilized eggs were washed to remove excess milts and ovarian fluid, and subjected to cold shock treatment to obtain triploid. Cold shock treatment was performed 5 min after fertilization, and the fertilized eggs were quickly placed in seawater with a water temperature of $0-2{ }^{\circ} \mathrm{C}$ for $45 \mathrm{~min}$. The processed fertilized eggs were gradually warmed to $15.0 \pm 0.5{ }^{\circ} \mathrm{C}$, and transferred to a $1.7 \mathrm{~m}^{3}$ seed production tank. During the period, diploid samples were used as controls, and the relative content of DNA was measured by Flow ploidy analyzer (CyFlow-S-3039, Partec) to detect the ploidy of the triploid samples. The induction rate of triploid larvae was $100 \%$, which was used for transplantation. Hatchling larvae were reared in the 
microalgae environment with $15-18{ }^{\circ} \mathrm{C}$ seawater, feeding on the intensified rotifers and brine worms, and gradually transformed into commercial feed or frozen fish.

\section{Cryopreservation of whole testes}

Donor sexually male individuals were sacrificed by anesthetic overdose with MS-222 (Sigma-Aldrich, USA). Testes were excised and transferred into $100 \mathrm{~mL}$ Eagle minimum essential medium (EMEM, GENOM, China) supplemented with $5 \%$ (vol/vol) fetal bovine serum (FBS) (Sijiqing, Hangzhou, China) and $25 \mathrm{mM}$ Hepes (Solarbio, Beijing, China), and kept on ice before use. The cryopreserved conditions were described previously [33]. The testes were transferred into $2 \mathrm{~mL}$ cryotubes containing $1 \mathrm{ml}$ cryomedium, which was composed of $10 \%$ (vol/vol) DMSO, 10\% (wt/vol) egg yolk, 0.1M D-(+)-trehalose dihydrate (Solarbio) and $40 \%$ (vol/vol) extender, and equilibrated on ice for $60 \mathrm{~min}$. Then the cryotubes were frozen at a rate of $-1{ }^{\circ} \mathrm{C} / \mathrm{min}$ for a period of 90 min by using a programmable freezer (Kryo-360-1.7, Planer Plc. Middlesex, UK) before being plunged into liquid nitrogen.

\section{Isolation, identification and labeling of donor cells}

After at least $3 \mathrm{~d}$ for cryopreservation, the testes were thawed. Approximately $1 \mathrm{~g}$ of testes were dissociated following the previously described methods [28], with a few modifications as below. The testicular tissue was finely minced and incubated in a dissociating solution containing $40 \mathrm{mg} / \mathrm{mL}$ Collagenase H (Roche, Switzerland), $33.3 \mathrm{mg} / \mathrm{mL}$ Dispase II (Roche), 5\% FBS and 1\% DNase I in $2 \mathrm{~mL}$ L-15 for $2.5 \mathrm{~h}$ at $25{ }^{\circ} \mathrm{C}$. The resultant cell suspension was sequentially filtered through $42 \mu \mathrm{m}$ filters to eliminate non-dissociated cell clumps, suspended in a discontinuous Percoll (Sigma-Aldrich) gradient of $45 \%, 35 \%, 25 \%$ and $10 \%$, and centrifuged at $800 \mathrm{~g}$ for $30 \mathrm{~min}$ at $4{ }^{\circ} \mathrm{C}$. In addition, part cell suspension was subjected to a cell viability test by the trypan blue $(0.4 \% \mathrm{w} / \mathrm{v})$ exclusion assay.

After density gradient centrifugation, all cell bands were harvested and observed under microscopy (Nikon, Japan). In order to confirm donor cell band, the RNA of all cell bands and the uncentrifuged cell suspension was extracted. Based on previous researches of spermatogonial stem cell markers, the stem-related genes oct4, nanos2 and plzf were used to identify spermatogonia by qPCR, as well as the universal germ cell marker of vasa as positive control $[43,44]$. The $\mathrm{qPCR}$ primers were shown in Table 1, and the method was described previously [45]. The results were analyzed by comparative $\mathrm{Ct}$ method. In this method, oct4, nanos2, plzf and vasa expression were normalized against Actin and GADPH expression, generating a $\Delta \mathrm{Ct}(\Delta \mathrm{Ct}=\mathrm{Ct}$ (oct4 or nanos 2 or plzf or vasa))-Ct $(\sqrt{\text { Actin } \times \text { GADPH }})$. Relative expression was calculated according to the equation, 2- $\Delta \Delta \mathrm{Ct}$, where the sample with the $\Delta \mathrm{Ct}$ of uncentrifuged cell suspension was taken as a calibrator.

According to the identification, donor cells were recommended for optimal staining with the fluorescent membrane dye PKH26 (Sigma-Aldrich) for $5 \mathrm{~min}$ according to manufacturer's instructions. After staining, the cells were washed twice with $3 \mathrm{~mL}$ L-15, and resuspended in another $200 \mu \mathrm{L}$ L-15 containing 1\% FBS. To detect whether the markers of PKH26 were positive cells, partial labeled cells were performed nuclear counterstain with $300 \mathrm{nM}$ DAPI (Sigma-Aldrich). The labeling cells were observed and photography under fluorescent microscope (Nikon). The total number of cells was estimated, and the cells were finally diluted to $1 \times 10^{6}$ cells $/ \mathrm{mL}$ and kept on ice until transplantation.

Table 1. Primers used in the study

\begin{tabular}{|c|c|c|c|}
\hline Primer & Sequence & Product size (bp) & Purpose \\
\hline ACTBF* & GTAGGTGATGAAGCCCAGAGCA & 204 & qPCR \\
\hline ACTBR* $^{*}$ & CTGGGTCATCTTCTCCCTGT & & \\
\hline GAPDHF* & TCCAATGTTTGTCATGGGAGTT & 101 & \\
\hline GAPDHR* & CCAGAGGAGCCAGGCAGTT & & \\
\hline oct $4 \mathrm{~F}$ & CTGTGTGGCGAGGAGTAGG & 132 & \\
\hline oct4R & TTGGATTGCTTTTGCGGA & & \\
\hline nanos $2 \mathrm{~F}$ & ACACCAGCAGTAGTTCCC & 223 & \\
\hline nanos $2 R$ & CTTGGCAGCATTTTCGCA & & \\
\hline plzfF & GAGGGTCAGGCTCAAGGC & 299 & \\
\hline plzfR & GCACACAGCAGACAGAAC & & \\
\hline vasaF & GTGGAGGTTACCGTGGAAAAGA & 162 & \\
\hline vasaR & AGTTGATGCCCTTCTCATAGTGG & & \\
\hline PovasF & CAGCCCAGCCACССАСАC & 280 & ISH \\
\hline PovasR & GTCTTTGCTTGGAACACA & & \\
\hline PoSP6R & $\begin{array}{l}\text { ATTTAGGTGACACTATAGAA } \\
\text { GTCTTTGCTTGGAACACA }\end{array}$ & & \\
\hline SmvasF & GAAGAATGGGAATAGAGC & 239 & \\
\hline SmvasR & GCTTGGAACACATTTATT & & \\
\hline SmSP6R & $\begin{array}{l}\text { ATTTAGGTGACACTATAGAA } \\
\text { GCTTGGAACACATTTATT }\end{array}$ & & \\
\hline PovasS & TCAATGCCCCCAGTAGTA & 567 & PCR \\
\hline PovasA & GTCTTTGCTTGGAACACA & & \\
\hline SmvasS1 & AGTTGGCTCAGTCCTTGG & 436 & \\
\hline SmvasA1 & GCTTGGAACACATTTATT & & \\
\hline SmvasS2 & ACACCTCGTTGTAGTTTT & 149 & \\
\hline SmvasA2 & GAAGAAGTCAAGAGATTA & & \\
\hline hybridvasF & GCAGCMCAGCCACССАСА & $268 / 282$ & \\
\hline hybridvasR & AGTCTTTGCTTGGAACAC & & \\
\hline
\end{tabular}

\section{The procedures of transplantation}

Japanese flounder PGCs were totally enclosed by somatic cells at 22 days post hatching (dph) and the elongated gonadal primordia appeared under the ventral kidney [47], so all transplantation experiments were carried out with triploid Japanese flounder 
before $22 \mathrm{dph}$. Considering the survival rate, 15-22 $\mathrm{dph}$ (the size about $3-5 \mathrm{~mm}$ ) larvae were finally selected as transplanted recipients. Every type of transplantation was repeated at least two times with more than 500 larvae, as shown in Table 2 . Transplantation needles were prepared by pulling thin glass capillaries (WPI, USA) using an electric puller (Narishige, Tokyo, Japan). The tips of the needles were ground to a $35^{\circ}$ angle and an opening of 20-30 $\mu \mathrm{m}$ diameter.

For transplantation, triploid Japanese flounder larvae were anaesthetised with $40 \mathrm{ng} / \mu \mathrm{L}$ MS-222 in seawater, and transferred onto a Petri dish coated with $2 \%$ agar. Donor cells were then transplanted into the coelomic cavity of the anaesthetized larvae using an oil pressure manual microinjection pump (Narishige) under a stereomicroscope. After transplantation, recipient larvae were transferred from the Petri dish to a $5 \mathrm{~L}$ recovery round plastic box filled with seawater containing $0.1 \%$ BSA and $15 \mathrm{mg}$ amoxicillin for three days, then transferred into nylon net hanging in the tank for two months, and released into the a $1.7 \mathrm{~m}^{3}$ larval rearing tank finally. Non-transplanted triploid larvae were also stocked at larval rearing tanks as control. The transplantation experiments were carried out in June each year from 2017 to 2019, and the transplantation and detection were repeated three times.

\section{Fluorescent observation of donor-derived cells}

Post-transplantation analysis of donor cells fate in triploid Japanese flounder recipients was first performed by fluorescent microscopy at 14 and 50 days after transplantation $(\mathrm{dpt})$. To confirm that PKH26-labeled donor cells were present in the peritoneal cavity and migrated to the genital ridge, 10 recipients were randomly selected to overall observe the abdomen at $14 \mathrm{dpt}$. And the ratios of donor cells migrated to the genital ridge of recipient were counted at $14 \mathrm{dpt}$. At $50 \mathrm{dpt}$, gonads were excised or exposed by tearing abdominal skin from 5 random recipients, then washed in $1 \times$ PBS and observed with the fluorescent microscope for examination of the distribution of donor cells. And the migration and colonization of donor cells were observed for three consecutive years, and the number of observations reached 45 individuals.

\section{Histology and in situ hybridization}

All gonads were removed and fixed overnight with Bouin's solution and $4 \%$ paraformaldehyde (PFA), respectively. Fixed samples were dehydrated through a graded series of ethanol, embedded in paraffin wax, and cut into $4 \mu \mathrm{m}$ thick sections and stained with $\mathrm{H} \& E$.
The turbot cells could be detected in triploid Japanese flounder by in situ hybridization (ISH) with species-specific probes. The primers (Table 1) used for probe synthesis were designed in the vasa 3'UTR regulatory region with low homology. For the antisense RNA probe synthesis process, briefly, the synthesis templates were the introduction of SP6 at the $3^{\prime}$ end of the fragment by 2 rounds of PCR; RNA probes were synthesized by in vitro transcription under the drive of SP6 promoter with the DIG RNA Labeling Kit (Roche, Mannheim, Germany); Then, RNA probes were purified with SigmaSpin ${ }^{\mathrm{TM}}$ Sequencing Reaction Clean-Up (Sigma-Aldrich). The gonad tissues were cut into $7 \mu \mathrm{m}$ thick sections, de-waxed and rehydrated. After washed with PBST, they were re-fixed using $4 \%$ PFA in PBS and digested with proteinase $\mathrm{K}(10 \mu \mathrm{g} / \mathrm{mL})$ for $10 \mathrm{~min}$. The ISH were performed with the probes at $65^{\circ} \mathrm{C}$ for $14 \mathrm{~h}$ and chemical stain with BCIP/NBT substrates.

\section{Immunohistochemistry}

In order to investigate whether donor-derived cells could proliferate in the xenogenic recipients, the gonad sections of $125 \mathrm{dpt}$ recipient after ISH were analyzed by immunohistochemistry. The sections were blocked in normal goat serum, treated with a 1:100 diluted anti-proliferating cell nuclear antigen (anti-PCNA) antibody (KGA324, Keygen Biotech Co., China) for $1 \mathrm{~h}$, and treated with a 1:50 diluted goat anti-mouse IgG-FITC secondary antibody (KGA324). After staining, the sections were incubated with DAPI staining solution for $5 \mathrm{~min}$. The sections were washed and observed through a fluorescent microscope (Nikon).

\section{PCR detection donor-derived spermatozoa or offspring}

The spermatozoa of 5 recipients at 2 years after transplantation (ypt) with turbot donor cells were released by squeezing the abdomen of the fish. Whole genomic DNA was extracted from the spermatozoa, and PCR was performed with specific primers designed in vasa $3^{\prime} \mathrm{UTR}$ (Table 1). PCR reactions were carried out in $25 \mu \mathrm{L}$ volume with $\mathrm{Q} 5 \AA$ Hot Start High-Fidelity 2X Master Mix (NEB, USA), according to the routine PCR procedure of Q5. An appropriate annealing temperature was estimated by using the NEB Tm Calculator. In order to detect a small amount of turbot DNA, nested PCR was carried out with 0.5 $\mu \mathrm{L}$ PCR production as template.

The spermatozoa of 3 recipients with summer flounder donor cells were collected as above, and performed artificial insemination with Japanese flounder eggs. Whole genomic DNA was extracted from 15 hybrid offspring and used for PCR to detect 
donor-derived DNA. The PCR was carried out with Q5, and primers designed in vasa 3'UTR (14 bp difference between 2 species) were shown in Table 1 . The PCR products were separated by electrophoresis on $2 \%$ agarose gel, then sent to sequence at Sangon Biotech.

\section{Scanning electron microscopy}

Subtle morphological and structural differences of turbot and Japanese flounder could be distinguished by scanning electron microscopy. Spermatozoa were fixed in $2.5 \%$ glutaraldehyde diluted in PBS ( $\mathrm{pH} 7.6)$, dehydrated in a series of increasing concentrations of ethanol, critical-point dried, evaporated with gold, and examined with a scanning electron microscope (JEOL JSM-840 SEM).

\section{Parentage test}

The spermatozoa from different recipients at 2 ypt were carried out artificial insemination with turbot or Japanese flounder eggs. Meanwhile, the spermatozoa (malformed) of triploid male controls were inseminated with Japanese flounder eggs. The fertilization rate and hatching rate were counted, and embryo development was tracked regularly. The offspring of turbot and the Japanese flounder were obviously different in appearance and can be distinguished by the naked eye. Early in the late embryonic development, it could also be identified through a microscope. But the hybrids of Japanese flounder and summer flounder were only identified by the aforementioned PCR test. The recipients from intra-species transplantation could evaluated by comparison with controls.

\section{Statistical analysis}

The software SPSS 26 was used for statistical analyses. The data of qPCR expression were subjected to one-way ANOVA followed by Tukey's test. All data are presented as mean \pm standard error (SE) of the different groups. Differences were considered significant at $\mathrm{P}<0.05$.

\section{Results}

\section{Isolation, identification and labeling of donor cells with enriched spermatogonia}

In the case of turbot, the testes of sexually mature male donors contained various stages of germ cells (Figure 1A1). There were a large number of type A undifferentiated spermatogonia (Aund), type A differentiated spermatogonia (Adiff) and type B spermatogonia (SpgB) distributed at the edge of the testes (Figure 1A1'). After whole testes cryopreservation, the isolated cells exhibited high survival rate $(90 \%)$ by trypan blue staining (Figure 1A1). In order to obtain enriched spermatogonia, the isolated cells were subjected to Percoll density gradient centrifugation, resulting in four distinct cell bands were generated in the tube (Figure 1A2-A5). The first band was observed on the top of $10 \%$ Percoll, containing a high percentage spermatogonia of type A (diameter 10-15 $\mu \mathrm{m}$ ) and B (diameter 6-10 $\mu \mathrm{m}$ ) and a few primary spermatocytes (diameter 4-6 $\mu \mathrm{m}$ ) (Figure 1A2); The second band on the top of $25 \%$ Percoll was thick and contained a lot of primary spermatocytes, secondary spermatocytes (diameter 3-4 $\mu \mathrm{m}$ ) and a few spermatids (diameter 2-3 $\mu \mathrm{m}$ ) (Figure 1A3); The third band was below of $35 \%$ Percoll, predominantly containing the spermatids and very few secondary spermatocytes (Figure 1A4); And the pellet on the bottom of the tube in $45 \%$ Percoll was the fourth band, and contained the most of spermatozoa (diameter $<2$ $\mu \mathrm{m})$ and a few spermatids (Figure 1A5).

The qPCR detected that the expression of four genes in isolated cells (Figure 1B). It demonstrated that vasa gene well expressed in uncentrifuged cell suspension and four cell bands, however, stem-related genes oct4, nanos2 and plzf kept higher expression in cells of the first band than others, especially for oct4 and nanos2 (Figure 1B). This identification results further confirmed that the first cell band contained ideal donor cells for transplantation.

Subsequently, the first cell band contained abundant spermatogonia was stained with PKH26 (Figure 1C). DAPI nuclear counterstain showed most of the cells were labeled by PKH26, of which spermatogonia accounted for $60 \%$ (Figure 1C). The PKH26 marker made it possible to trace donorderived cells in the body cavity of recipients during early transplantation. The isolation, identification and labeling of donor cells in Japanese flounder and summer flounder were similar to those of turbot.

\section{Assessment the migration and colonization rates of transplanted donor cells in recipients}

PKH26-labeled donor cells of turbot were observed in recipients at $14 \mathrm{dpt}$, and the cells almost migrated to the genital ridge (Figure 2B1-B3), while the control group showed no fluorescence at the same location (Figure 2A1-A3). At $50 \mathrm{dpt}$, the donor cells randomly distributed and incorporated into the developing recipient gonad (Figure 2C1-C3, D1-D3). Like turbot, the labeled donor cells of summer flounder and Japanese flounder were found in genital ridge at $14 \mathrm{dpt}$ (Figure S1A1-A3, B1-B3) and exposed gonads of recipients at $50 \mathrm{dpt}$, respectively (Figure 2E1-E3, F1-F3). 

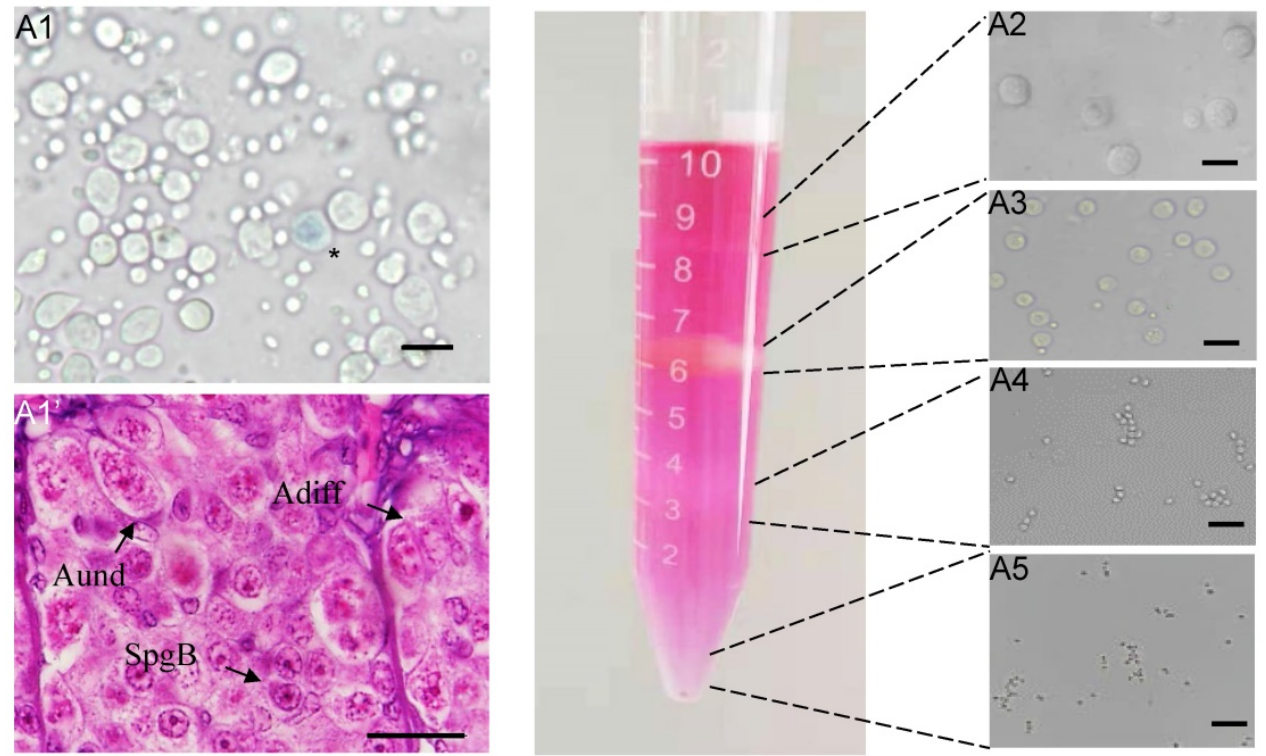

B
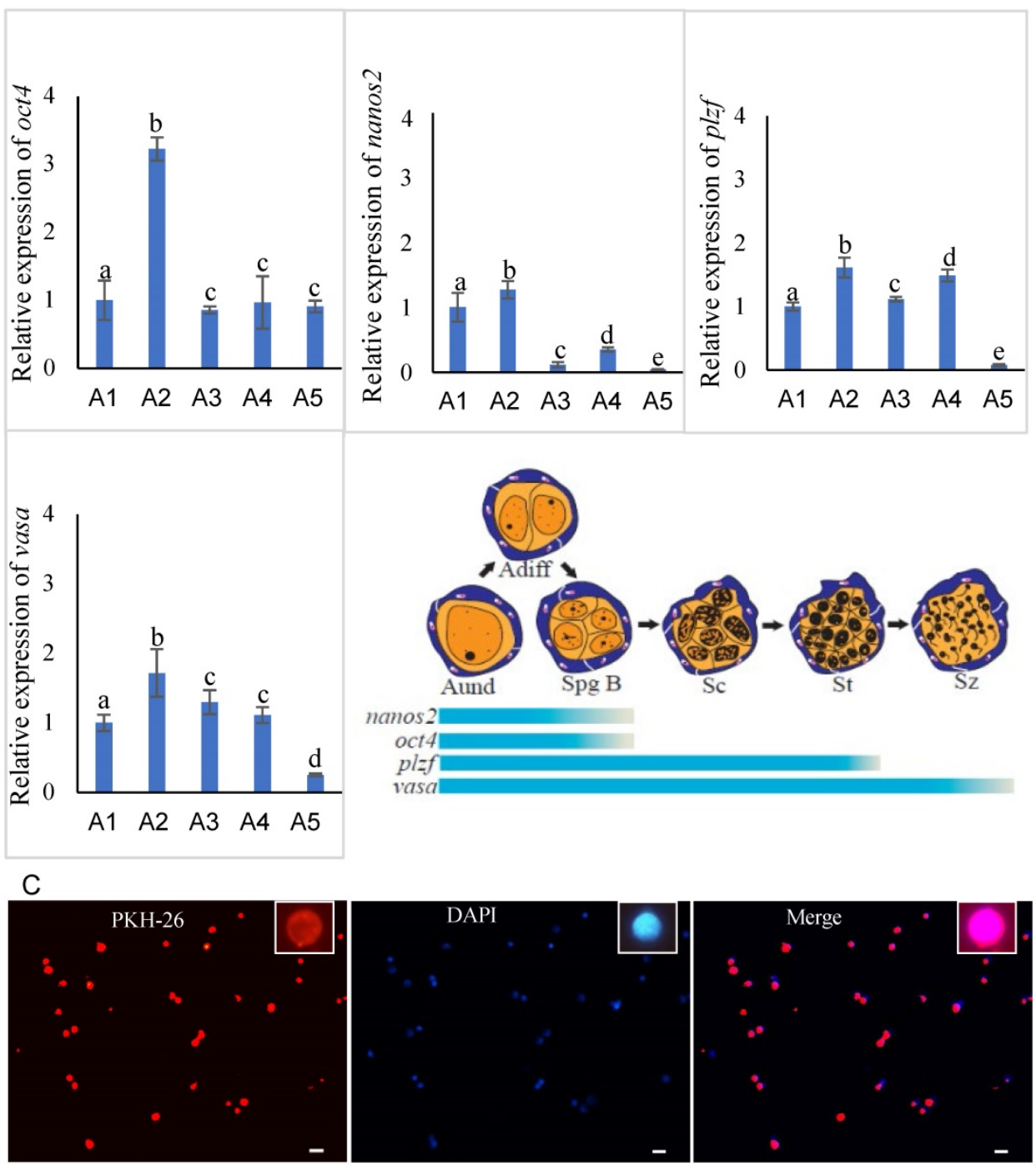

Figure 1. Isolation, identification and labeling of donor cells from sexually mature male turbot. (A1) The survival rate of cells in the testes after whole cryopreservation were determined by trypan blue staining. (A1') Histology of germ cells distributed at the edge of the testes. (A2-A5) Four distinct cell bands were generated in the tube after Percoll density gradient centrifugation. (B) The qPCR was used to detect the expression of oct4, nanos2, plzf and vasa genes in isolated cells. (C) The first cell band was stained with PKH26 and DAPI. The asterisk in Al indicated dead cell. Aund: type A undifferentiated spermatogonia; Adiff: type A differentiated spermatogonia; SpgB: type B spermatogonia. Different letters indicated statistically significant differences $(P<0.05)$. The insets were magnification of one spermatogonia. Scale bar, $15 \mu \mathrm{m}$. 

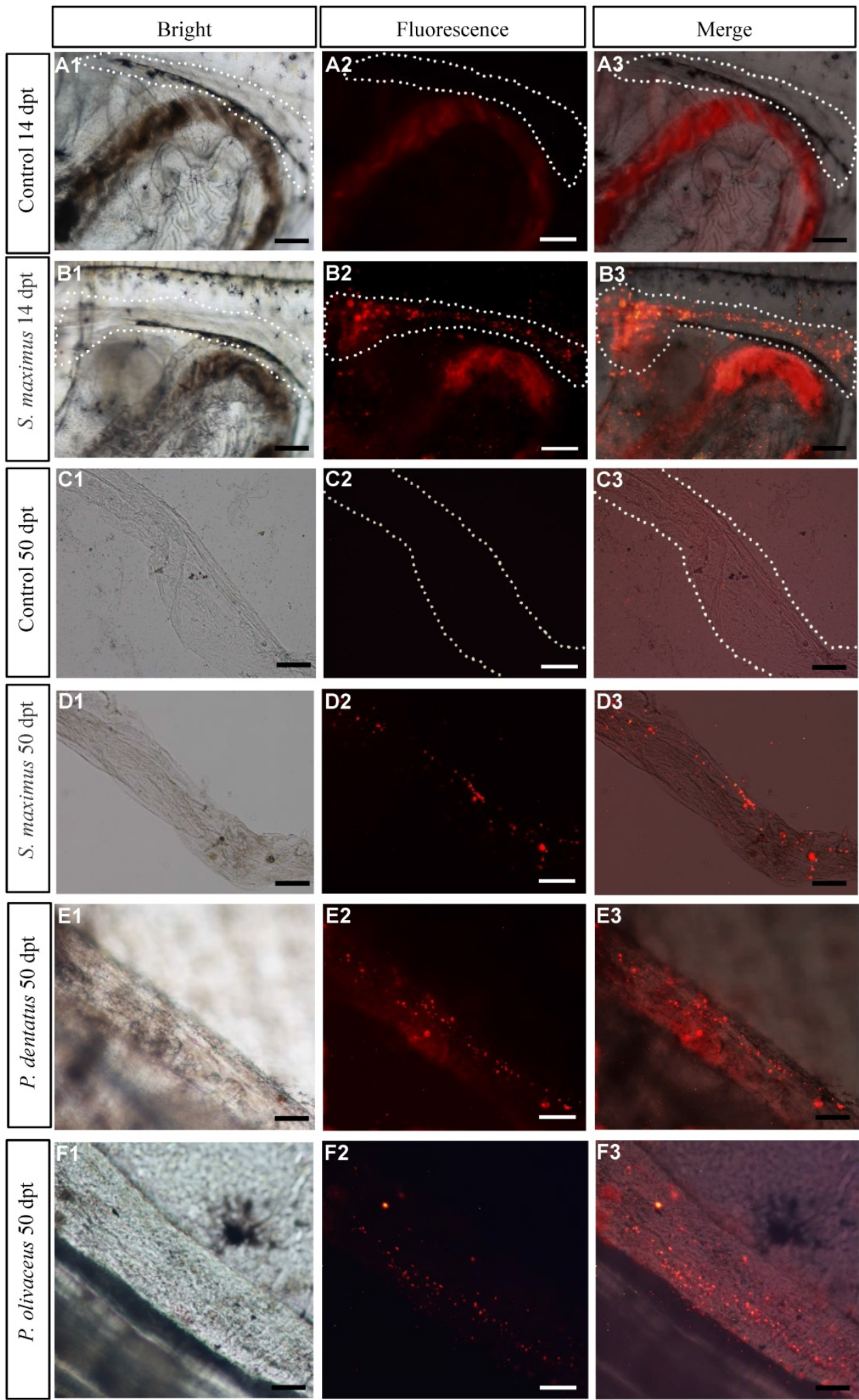

Figure 2. Assessment the migration and colonization rate of transplanted donor cells in recipients. (A1-A3, B1-B3) Observation PKH26-labeled cells of turbot at genital ridge of $14 \mathrm{dpt}$ recipients and controls, respectively. (CI-C3, DI-D3) Observation PKH26-labeled cells of turbot in removed gonads of $50 \mathrm{dpt}$ recipient and controls, respectively. (EI-E3, FI-F3) Observation PKH26-labeled cells of summer flounder and Japanese flounder in exposed gonads of recipients at 50 dpt, respectively. Scale bar, 100 $\mu \mathrm{m}$.

The early assessment of transplantation efficiency by observation fluorescence in genital ridge at $14 \mathrm{dpt}$. As the days of hatching increased, the survival rate of transplanted recipients gradually increased, while the transplantation efficiency decreased (Table 2). And Japanese flounder (100\%) 
and summer flounder $(95.00 \% \pm 0.71)$ had higher colonization rates than turbot $(43.33 \% \pm 1.53)$ (Table 2).

Table 2. The survival of $14 \mathrm{dpt}$ recipients and colonization rates of transplanted donor cells

\begin{tabular}{llllll}
\hline Donors & $\begin{array}{l}\text { Recipients } \\
(\mathrm{dph})^{\mathrm{b}}\end{array}$ & $\begin{array}{l}\text { No. every } \\
\text { group }\end{array}$ & No. survived (\%) & $\begin{array}{l}\text { No. } \\
\text { observed }\end{array}$ & $\begin{array}{l}\text { No. } \\
\text { colonized }^{\mathrm{d}}\end{array}$ \\
\hline Turbot & 15 & 356 & $148(41.57)$ & 10 & 6 \\
& 18 & 462 & $246(53.25)$ & 10 & 4 \\
& 21 & 186 & $114(61.29)$ & 10 & 3 \\
Japanese & 16 & 495 & $215(43.43)$ & 10 & 10 \\
flounder & 19 & 343 & $187(54.52)$ & 10 & 10 \\
& 22 & 182 & $112(61.54)$ & 10 & 10 \\
Summer & 17 & 288 & $143(49.65)$ & 10 & 10 \\
flounder & 20 & 224 & $124(55.36)$ & 10 & 9 \\
Controla & $/$ & 500 & $316(63.20)$ & 10 & 0 \\
\hline
\end{tabular}

a Control means non-transplanted triploid Japanese flounder group.

b Triploid Japanese flounder larvae were used as recipients for transplantation on different days after hatching.

c Number of recipient fish whose genital ridges were observed under fluorescent microscopy.

d Number of recipient fish whose genital ridges were found to possess the PKH26-labeled cells.

\section{Analysis gonad development and sexual differentiation of recipients}

Gonadal morphology of recipients transplanted turbot donor cells was evaluated at different development stages. Histology showed that under normal culture conditions, the ovaries of diploid turbot and Japanese flounder, including oocytes at various stages (I-IV), reached sexual maturity at 3 years old (Figure 3A, C). While the ovary of triploid Japanese flounder contained a large number of early oocytes (I-II) at 3 years (Figure 3E). The testis of diploid turbot at 2 years was found only a few spermatids and no matured spermatozoa until 3 years (Figure 3B, B'). However, for diploid Japanese flounder, the spermatozoa matured at 2 years old (Figure 3D). Although the matured triploid Japanese flounder contained spermatozoa, most of them were deformed and lacked flagellum (Figure 3F). For the types of spermatozoa maturation, in Japanese flounder, the germ cells at various stages developed in the spermatocysts arranged at the periphery of the lobules till the spermatozoa, then released to the lobular Lumen (Figure 3D). However, in turbot, when the germ cells developed to the secondary spermatocytes stage, the boundary between the spermatocysts became not obvious, and mixed together (Figure 3B).

Generally, the gonads of flatfish are paired, the testes are bilobed structure, and the ovaries are club-shaped. The appearance of recipient gonads was identified as testes, which showed typical structure of lobular-type on tissue sections (Figure 3G1-G2, I1-I2). The testis was composed of many spermatocysts, including male germ cells at different developmental stages, such as spermatogonia and spermatocytes, spermatids and spermatozoa in recipients at $2 \mathrm{ypt}$ (Figure 3G1-G2). The testis of recipient at $3 \mathrm{ypt}$ was more matured and produced a large number of spermatozoa (Figure 3I1-I2).

According to the appearance, the gonads of recipients at 2 ypt were identified as ovaries, which showed the structural characteristics of the ovigerous lamella on tissue sections (Figure 3H1-H3). But besides oogonia, it also contained a few spermatids even spermatozoa (Figure 3H1-H3). When they developed for 3 years old, a few early oocytes (I-II) were found, and a number of male germ cells at various stages were also observed, containing spermatogonia, spermatocytes, and even some spermatids and spermatozoa (Figure 3J1-J2). There were two different types of germ cells in recipient gonads, including male and female germ cells, which were referred to intersex (Figure 3H1-H3, J1-J2). Sex ratio was calculated according to the anatomy and histology of the gonads. In short, the ratio of intersex to male was about 1:1, as shown in Table 3.

\section{Detection donor-derived cells and proliferation in recipients}

The vasa gene was used as a specific marker of germ cells for identifying turbot germ cells from transplanted triploid Japanese flounder gonad. ISH confirmed that both probes were specifically hybridized with vasa mRNA from turbot and Japanese flounder gonads, respectively (Figure 4A1-A8). And the vasa signals were predominantly detected in early germ cells, such as spermatogonia, spermatocytes, oogonia and early oocytes (I-III), and no signal was detected in spermatids, spermatozoa, and relatively mature oocytes (Figure 4A1-A8). When serial gonad sections of $125 \mathrm{dpt}$ recipient were hybridized with species-specific probes, the Japanese flounder vasa signals were widely presented in the whole gonadal germ cells, while the turbot signals only existed in a cluster of germ cells (Figure 4B1-B2). Refer to H\&E staining, the germ cells were mostly composed of SpgB (Figure 4B3).

Cell proliferation was detected at $125 \mathrm{dpt}$ recipient by immunohistochemistry with anti-PCNA antibody after ISH. The SpgB were identified by DAPI staining and showed strong green fluorescence after treated with anti-PCNA antibody (Figure 4C1-C2). The merged image demonstrated the proliferation of germ cells, including the donor-derived cells (Figure 4C3). These results showed that the germ cells of turbot proliferated in the somatic microenvironment of triploid Japanese flounder gonad. 

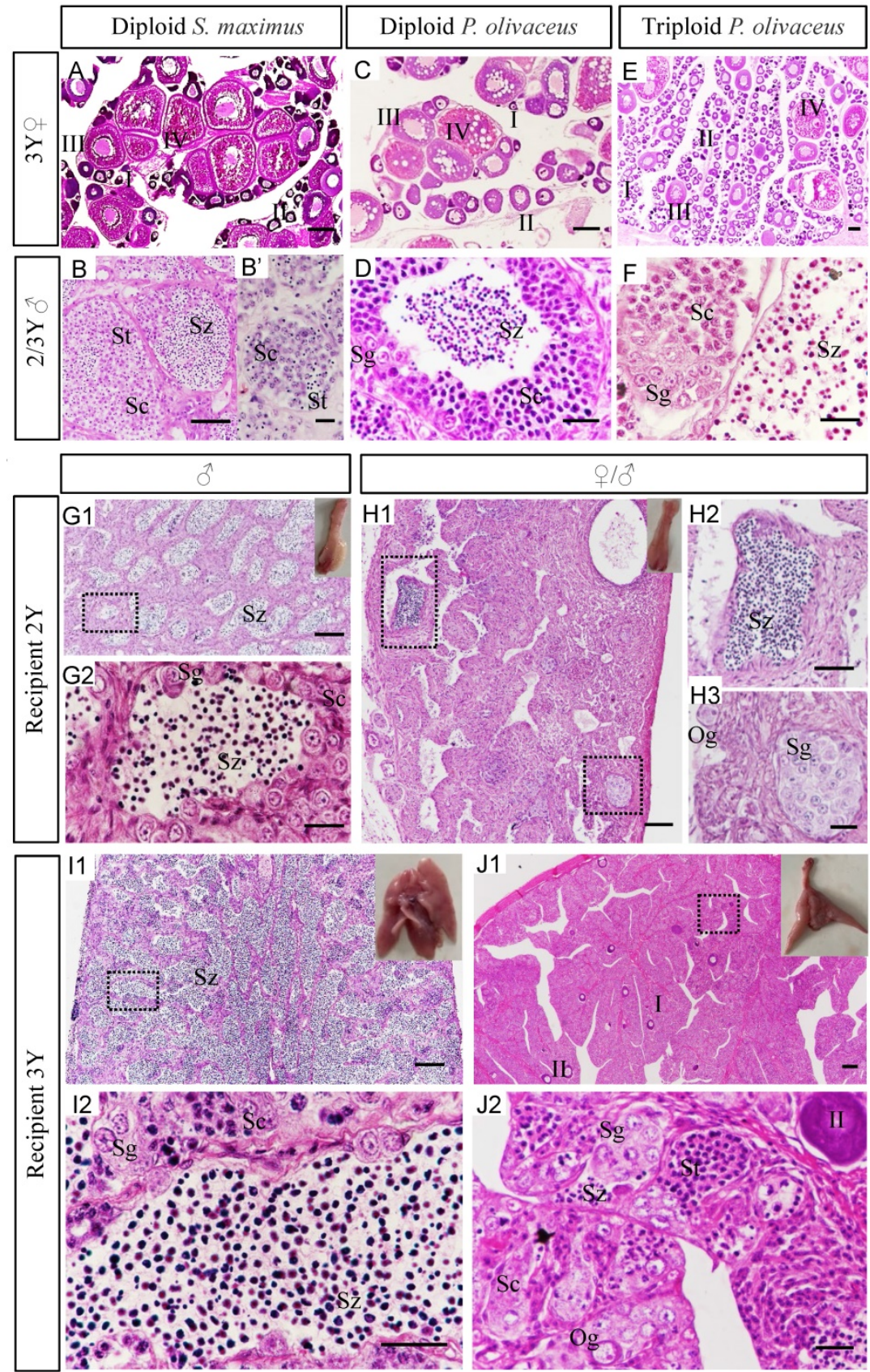

Figure 3. Analysis gonad development and sexual differentiation of recipients by histology. (A-F) The gonads of controls at 2 -3 years old. The ovaries of diploid turbot (A), diploid Japanese flounder (C) and triploid Japanese flounder (E) at 3 years old. The testis of diploid turbot at 2 years (B') and 3 years (B), diploid Japanese flounder at 2 years (D), and triploid Japanese flounder at 3 years (F). (G1-J2) The gonads of recipients transplanted turbot spermatogonia at 2-3 years old. The recipient of male at 2 ypt (G1-G2) and 3 ypt (11-12). The recipient of intersex at 2 ypt (H1-H3) and 3 ypt (J1-J2). G2, H2, H3, 12, J2 were the amplification of black dotted frame in G1, H1, I1, J1, respectively. The insets showed appearance of chimeric gonads. I-II, early/late previtellogenic phase; III-IV, early/late vitellogenic phase; Sg, spermatogonia; Scl, primary spermatocytes; Sc2, secondary spermatocytes; St, spermatids; Sz, spermatozoa. Scale bar, $100 \mu \mathrm{m}$ (A, C, E, G1, H1, II, J1); $50 \mu \mathrm{m}$ (B, D, F, G2, H2, H3, I2, J2); $10 \mu \mathrm{m}$ (B').

Table 3. Detection donor-derived cells from recipients at different stages

\begin{tabular}{|c|c|c|c|c|c|c|c|}
\hline \multirow[t]{2}{*}{ Donors } & \multicolumn{7}{|c|}{ Recipients } \\
\hline & Age & No. survived (\%) & No. detected & Detection method & Sex ratio & Insemination hatching rate & No. positive \\
\hline \multirow[t]{3}{*}{ Turbot } & $1 \mathrm{Y}$ & 34.10 & 4 & ISH & 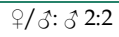 & / & 2 \\
\hline & $2 Y$ & 10.02 & 8 & ISH & 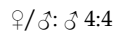 & $2 \% 00$ & 2 \\
\hline & $3 Y$ & 5.04 & 7 & ISH/PCR & 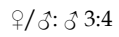 & $2 \% 00$ & 3 \\
\hline Japanese flounder & $2 Y$ & 6.83 & 4 & Insemination & 우: §̋ 2:2 & $50-60 \%$ & 4 \\
\hline Summer flounder & $2 \mathrm{Y}$ & 3.98 & 4 & Hybrid/PCR & †: § $2: 2$ & $40-50 \%$ & 3 \\
\hline Diploid controla $^{a}$ & $3 Y$ & 40.31 & 10 & Histology & ㅇ: & $90-95 \%$ & 0 \\
\hline Triploid control ${ }^{b}$ & $3 Y$ & 27.08 & 10 & Histology & 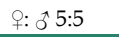 & $1 \%$ & 0 \\
\hline
\end{tabular}

a Control means non-transplanted diploid Japanese flounder group.

b Control means non-transplanted triploid Japanese flounder group.

cNumber of recipients whose gonads were found to include the donor-derived cells. 

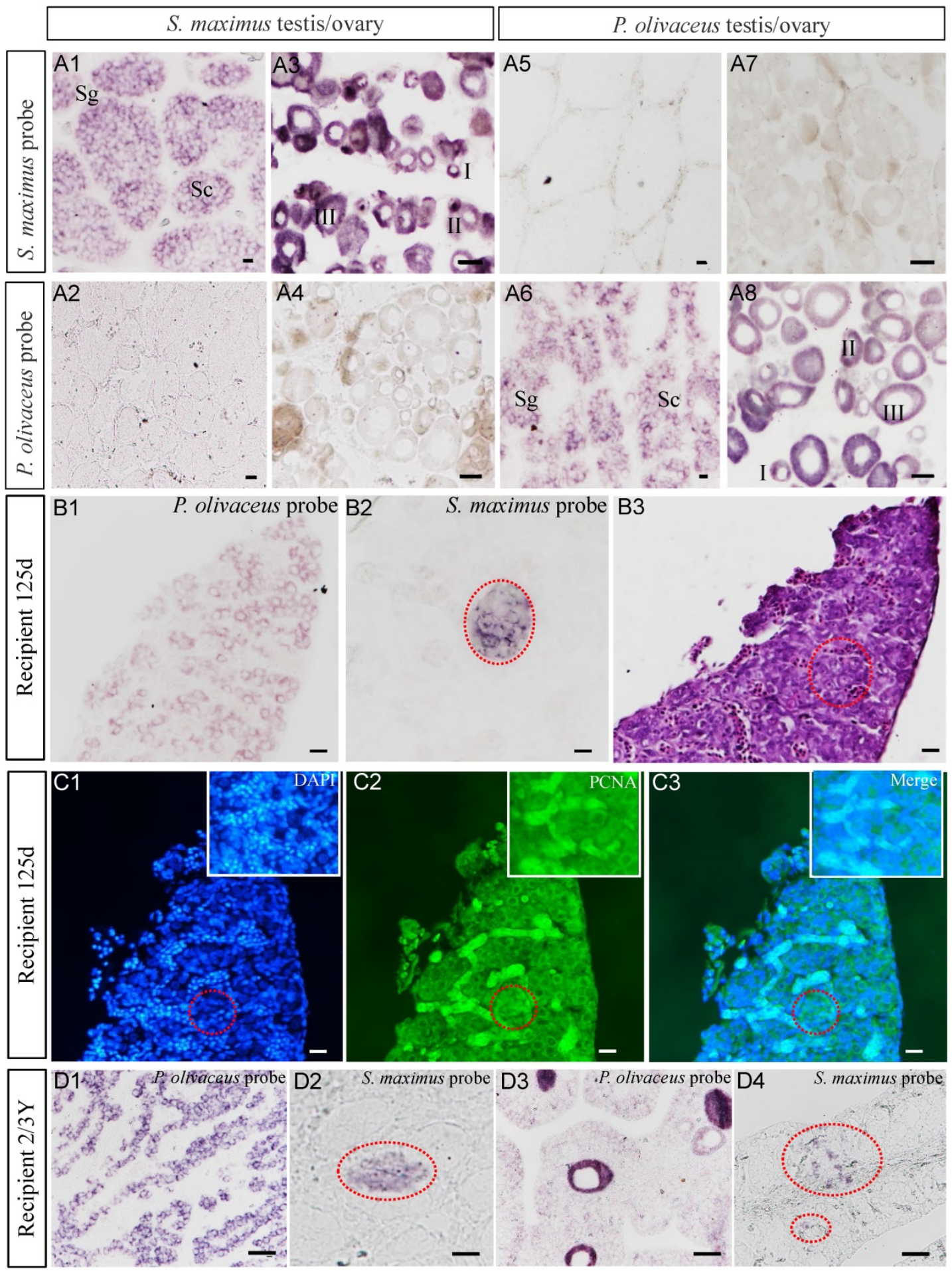

Figure 4. Detection donor-derived cells and proliferation in recipients by ISH and immunohistochemistry. (AI-A8) ISH confirmed the species-specific probes of turbot and Japanese flounder. (B1-B3) Detected donor-derived germ cells from recipients at $125 \mathrm{dpt}$ by ISH and adjacent histology. (C1-C3) Detected the proliferation of donor-derived germ cells by immunohistochemistry with anti-PCNA antibody after ISH. (D1-D2, D3-D4) The donor-derived germ cells were continued to trace from male chimeras at 2 ypt and intersexual chimeras at 3 ypt, respectively. I-II, early/late previtellogenic phase; III, early vitellogenic phase; Sg, spermatogonia; Sc, spermatocytes; The red dotted circle represented the turbot signal area of $\mathrm{ISH}$, and the insets in $\mathrm{C} 1-\mathrm{C} 3$ were the amplification of the signal area. Scale bar, $10 \mu \mathrm{m}(\mathrm{A} 1, \mathrm{~A} 2, \mathrm{~A} 5, \mathrm{~A} 6, \mathrm{~B} 1-\mathrm{C} 3)$; $50 \mu \mathrm{m}(\mathrm{A} 3$, A4, A7, A8, D1-D4).

Similarly, at 2-3 years old, the donor-derived germ cells, such as spermatogonia and spermatocytes, were identified from transplanted triploid Japanese flounder gonads (Figure 4D1-D4). Interestingly, we found turbot germ cells of spermatogonia and spermatocytes from the intersexual recipient gonad, which also included Japanese founder early oocyte and male germ cells (Figure 4D3-D4). All of the above results showed that donor-derived cells existed throughout the development of the recipient gonads. 

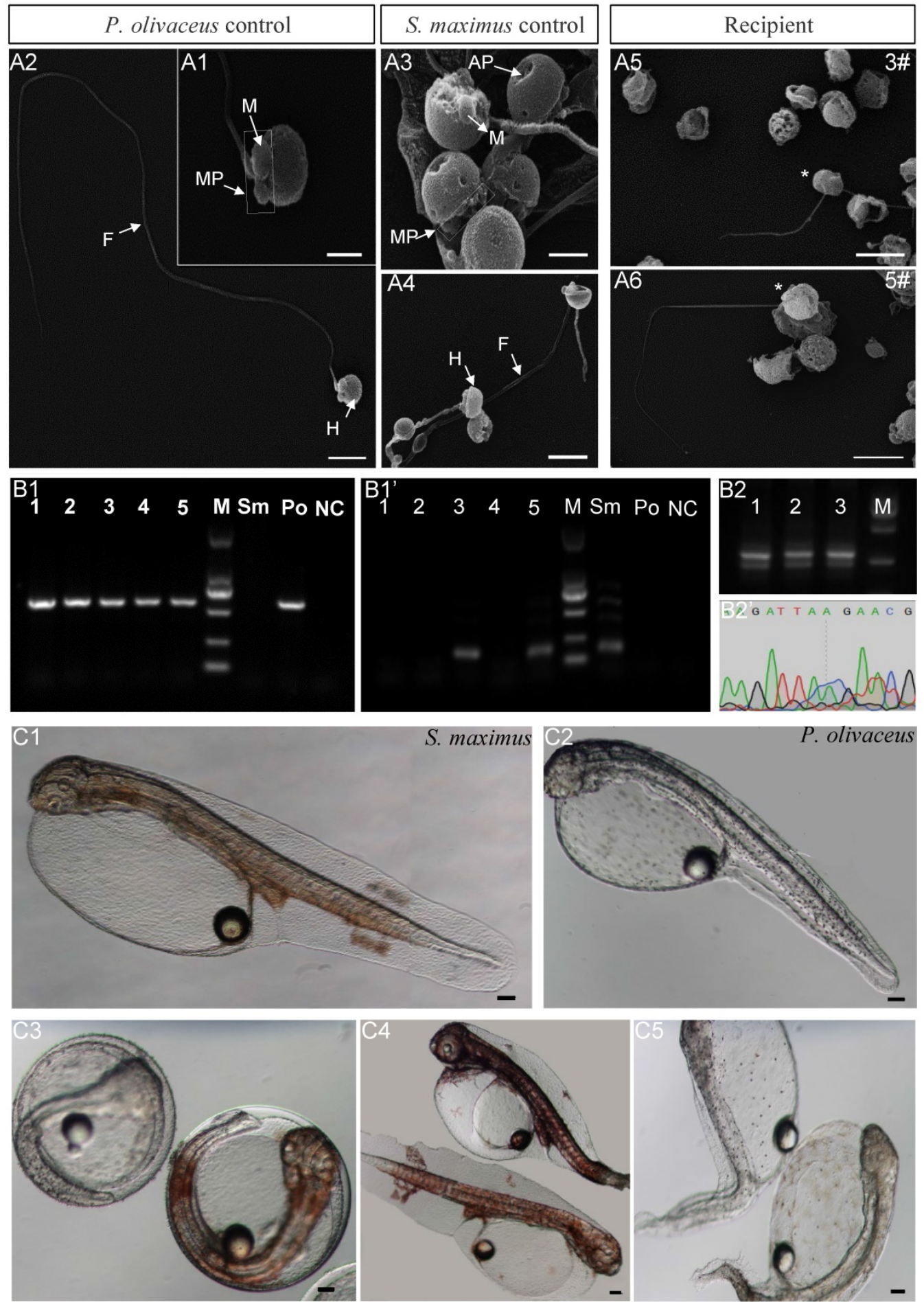

Figure 5. Identification donor-derived spermatozoa or offspring from matured recipients. (A1-A6) Observation spermatozoa morphology from 5 recipients in inter-family transplantation by scanning electron microscopy. The asterisk indicated turbot spermatozoa. H: head; MP: mid-piece; F: flagellum; M: mitochondrion; AP: Anterior pit of nucleus. (B1-B1') Detection spermatozoa DNA from 5 recipients in inter-family transplantation by nested PCR. (B2-B2') Identification the hybrids from 3 recipients in intra-genus transplantation by the $2 \%$ agarose gel electrophoresis and sequencing after PCR. Sm: turbot positive control; Po: Japanese flounder positive control; NC: negative control; M: marker 2000. (C1-C3) The body colors larva of turbot and the Japanese flounder. (C4) The recipients $3 \#$ and $5 \#$ could produce 2 turbot offspring by artificial insemination, respectively. (C5) As control, the embryos from triploid Japanese flounder were all malformed and died during the process of development. Scale bar, $1 \mu \mathrm{m}$ (A1, $\mathrm{A} 3) ; 2.5 \mu \mathrm{m}$ (A2, A4); $4 \mu \mathrm{m}(\mathrm{A} 5, \mathrm{~A} 6) ; 100 \mu \mathrm{m}(\mathrm{C} 1-\mathrm{C} 5)$.

\section{Identification donor-derived spermatozoa or offspring from matured recipients}

The morphology and function of donor-derived spermatozoa from inter-family transplantation were identified by scanning electron microscopy, PCR and artificial insemination. The spermatozoa of both species consisted of three parts: head, mid-piece and flagellum (Figure 5A1-A4). However, the shape of spermatozoa head was different. For Japanese 
flounder spermatozoa, the long diameter was $1.60 \pm 0.50 \mu \mathrm{m}$, and the short diameter was $1.50 \pm 0.50$ $\mu \mathrm{m}$ (Figure 5A1-A2). While for turbot, due to the anterior pit of nucleus, the long diameter was $1.70 \pm 0.50 \mu \mathrm{m}$, and the short diameter was $0.80 \pm 0.50$ $\mu \mathrm{m}$ (Figure 5A3-A4). The spermatozoa of 5 recipients at 2 ypt were observed, in which the recipients $3 \#$ and $5 \#$ contained scattered turbot spermatozoa with anterior pit of nucleus (Figure 5A5-A6). Besides, the recipients contained a large number of triploid Japanese flounder spermatozoa with malformed or totally absent from flagellum (Figure 5A5-A6). Then, PCR was performed with species-specific primers to identify turbot DNA from the spermatozoa in 5 recipients. The results showed that all 5 recipients contained Japanese flounder DNA (Figure 5B1). And the turbot DNA was also detected in the recipients $3 \#$ and $5 \#$ by nested PCR (Figure 5B1'). In order to further analyze the spermatozoa function, artificial insemination was carried out for 5 recipients. The larva of turbot and the Japanese flounder showed different body colors. Turbot larvae showed obvious orange pigment clusters from somite stage on the dorsal and anal fin folds, while Japanese flounder larvae was covered with melanin dots (Figure $5 \mathrm{C} 1-\mathrm{C} 3)$. The fertilization rate and hatching rate of the five recipients were kept at a very low level $(2 \%$ ) only the recipients $3 \#$ and $5 \#$ could produce 2 turbot-like offspring, respectively (Table 3, Figure 5C4). Because the hybrid between turbot and Japanese flounder could not develop normally, the 2 offspring obtained from artificial insemination were donor derived.

And the triploid Japanese flounders were transplanted with allogeneic spermatogonia, the fertilization rate was as high as $90 \%$. But some embryos died at the blastula stage, and others gradually stabilized after the gastrulation, resulting in the hatching rate at $50-60 \%$ (Table 3 ). As controls, the embryos from diploid developed well under breeding conditions, keeping the fertilization rate and hatching rate at high level (90-95\%), and the embryos from triploid were all malformed and died during the process of development (Table 3, Figure 5C5).

At the same time, the spermatozoa of 3 recipients transplanted summer flounder germ cells were hybridized with Japanese flounder eggs. The hatching rate of recipients $1 \#$ and $3 \#$ were $50-60 \%$, which was not significantly different from above intra-species transplantation (Table 3). And the recipients 2\# kept $30 \%$, which was relatively low (Table 3 ). The PCR results of hybrids from 3 recipients showed that there were two bands with similar molecular sizes on $2 \%$ agarose gel electrophoresis. After sequencing, double peaks appeared in the different sequence regions of
Japanese flounder and summer flounder, which further confirmed that they contained the DNAs of two species (Figure 5B2-B2').

\section{Discussion}

The present study demonstrated the successful intra-species, intra-genus and inter-family GCT within Pleuronectiformes. We transplanted Japanese flounder, summer flounder, and turbot spermatogonia into the peritoneal cavities of triploid Japanese flounder larvae, and achieved donorderived functional spermatozoa from recipients, respectively (Figure 6). This firstly realized inter-family transplantation in marine fish species and shortened the maturation time of turbot spermatozoa.

In previous studies, fish GCT within family level had been reported in many species, including transplanting Niber croaker spermatogonia into allogeneic larvae (intra-species)[12], Pejerrey $(O$. bonariensis) spermatogonia into adult patagonian pejerrey (O. hatcheri) (intra-genus)[48], and Atlantic salmon (S. salar) spermatogonial cells into rainbow trout larvae (inter-genus)[49]. And donor-derived gametes and offspring were successfully produced. However, as the phylogenetic distance between the donor and recipient gradually becomes greater, especially for species belonging to a different family or order, the transplantations are difficult to succeed. So far, in freshwater fish, only the successful inter-family transplantation of loach (M. anguillicaudatus) and zebrafish (D. rerio) and inter-order transplantation of Jundia catfish (R. quelen) and Nile tilapia (O. niloticus) has been reported [10, 50]. In marine fish, there is no successful transplantation beyond family level. Due to the large body size, long maturation period, complicated reproduction regulation and cultivation conditions of commercially important species, the transplanted germ cells often cannot develop and mature in the recipients $[5,27,28]$. The inter-family transplantations were tried in southern bluefin tuna (T. maccoyii) to yellowtail kingfish (S. lalandi), as well as Japanese yellowtail to Niber croaker, the transplanted cells only migrated to the genital ridge and proliferated in developing gonad, but disappeared at later stages [5, 28]. In this study, we successfully transplanted the Japanese flounder, summer flounder, and turbot spermatogonia into triploid Japanese flounder larvae. Transplantation efficiency of turbot-Japanese flounder $(33-50 \%)$, summer flounder-Japanese flounder (75-95\%) and Japanese flounder-Japanese flounder $(100 \%)$ was achieved by fluorescence tracking and molecular analysis. Subsequently, the donor-derived spermatozoa function was further confirmed by artificial insemination. These results demonstrated 

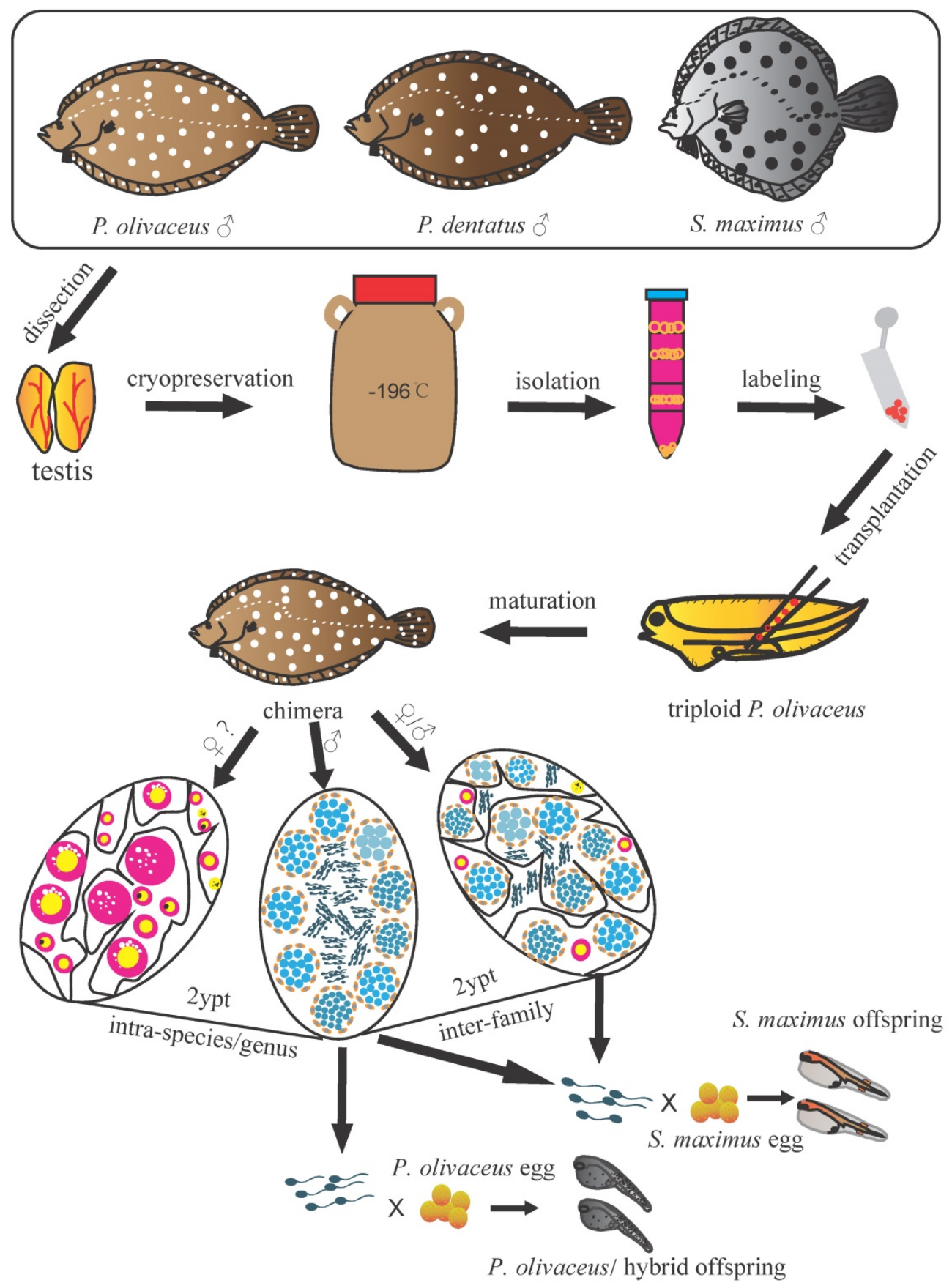

Figure 6. Schematic illustration of spermatogonial stem cell transplantation whin Pleuronectiformes. The spermatogonia of Japanese flounder, summer flounder, and turbot were isolated from cryopreserved whole testes, then labeled and transplanted into the peritoneal cavities of triploid Japanese flounder larvae. The transplanted recipients differentiated into male and female chimeras in intra-species and intra-genus transplantations, and only male and intersex chimeras in inter-family transplantations. Finally, donor-derived spermatozoa and the offspring by artificial insemination were obtained from recipients at 2 ypt, respectively.

germ cells from allogeneic or xenogeneic species within Pleuronectiformes were able to migrate, colonize, proliferate, differentiate and mature in recipients, and finally produce donor-derived spermatozoa and offspring. This also indicated even in divergent phylogenetic relationship, donor-derived germ cells could recognize and respond to the guide signals under the regulation of the recipient developmental environment, eventually mature in the recipient $[10,50]$.
Interestingly, we also found that the sex differentiation of recipients was influenced by donor germ cells. The previous study showed that recipients in the transplantations between species of closed phylogenetic relationship could produce functional donor-derived spermatozoa and eggs [18, 34, 51]. However, transplantations between species of highly divergent in evolution were usually difficult to succeed, and only a few recipients differentiated into males that produced functional spermatozoa, without 
females or functional eggs $[6,50,52]$. Donor germline stem cells produce gametes based on the gender of the recipient, not their own gender [26]. In this study, we obtained normal developed male and female chimeras in intra-species and intra-genus transplantations, and the male chimeras produced the functional spermatozoa, although the female chimeras were currently immature. In inter-family transplantation, we only obtained male and intersex chimeras, with a ratio of approximately 1:1, and no female chimeras. The gonad of male chimeras also developed normally, and produced donor-derived functional spermatozoa. The gonad of intersex chimeras showed ovary morphology and structure, however it contained turbot male germ cells that could continue to develop into functional spermatozoa, besides Japanese flounder female (a few early oocytes) and male germ cells. Compared with the non-transplantation female triploid Japanese flounder control, the introduction of exogenous spermatogonia inhibited the development of oocytes in the recipients, and promoted the regulation of the recipient to develop toward masculinization. That indicated that the recipients of Japanese flounder sex differentiation direction might be more susceptible to the influence of external germline stem cells.

In addition, Japanese flounder produced turbot spermatozoa, which shortened the turbot spermatozoa production time from 3 year to 2 year. Under artificial breeding conditions, turbot generally does not reach sexual maturity until three years old. And turbot spermatogenesis type belongs to semicystic type, in which the cyst ruptures at the spermatocyte or spermatid stage, so spermatozoa mixed other germ cells are released into the lumen $[53,54]$. In contrast, the Japanese flounder belongs to cystic type, in which the spermatogenesis process takes place entirely inside the cyst and the spermatozoa are released into the lumen after the cyst breaks [55]. The histology results showed the turbot spermatogenesis conformed to the recipients during the process of testis development and maturation. In inter-family transplantation between Japanese flounder and turbot, the Japanese flounder still could surrogate the turbot for gametes production, although the donor and recipient required different water temperature and photoperiod control to regulate gonad maturation, even their spermatogenesis belonged totally two different spermatogenesis types, suggesting that the mechanisms underlying donor germ cells migration, incorporation and maturation in recipients were conserved across a wide range of teleost species [48-50]. Moreover, the turbot cells were transplanted at hatched Japanese flounder larvae stage, and remained in the recipients for a longer period (more than 2 years) compared with previous distant transplantations [10, 28, 50]. It is totally possible to transplant germ cells from large-bodied commercially important marine fish species and endangered species to related small and easier to breed species.

In conclusion, we successfully transplanted the Japanese flounder, summer flounder, and turbot spermatogonia into triploid Japanese flounder larvae, and achieved donor-derived functional spermatozoa from recipients, respectively. We also found that the transplanted recipients differentiated into male and female chimeras in intra-species and intra-genus transplantations, and only male and intersex chimeras in inter-family transplantations. Moreover, the intersex chimeras could mature and produce turbot functional spermatozoa. This firstly realized inter-family transplantation in marine fish species and shortened the maturation time of turbot spermatozoa. The results of this study promote the understanding the mechanism of the germ stem cells differentiation and maturation, and provide an alternative approach for the breeding of marine fish and the preservation of genetic resources.

\section{Abbreviations}

GCT: germ cell transplantation technology; PGCs: primordial germ cells; dnd-MO: dead end-knockdown; FBS: fetal bovine serum; dph: days post hatching; dpt: days after transplantation; PFA: paraformaldehyde; ISH: in situ hybridization; ypt: years after transplantation; Aund: type A undifferentiated spermatogonia; Adiff: type A differentiated spermatogonia; SpgB: type B spermatogonia.

\section{Supplementary Material}

Supplementary figure.

https://www.ijbs.com/v17p4426s1.pdf

\section{Acknowledgements}

This work was supported by the National Key Research and Development Program (2018YFD 0901205, 2018YFD0901204), Financially supported by the Marine S\&T Fund of Shandong Province for Pilot National Laboratory for Marine Science and Technology (Qingdao) (2018SDKJ0302-4), Shandong Provincial Natural Science Foundation (ZR2020KC038), China Agriculture Research System (CARS-47), Major science and technology for scientific and technological innovation projects (Shandong) (2019JZZY020710) and Major Agricultural Application Technology Innovation Project of Shandong Province (SD2019YY011). 


\section{Competing Interests}

The authors have declared that no competing interest exists.

\section{References}

1. Shigunov P, Dallagiovanna B. Stem Cell Ribonomics: RNA-Binding Proteins and Gene Networks in Stem Cell Differentiation. Front Mol Biosci. 2015; 2: 74.

2. Lee S, Iwasaki Y, Yoshizaki G. Long-term (5 years) cryopreserved spermatogonia have high capacity to generate functional gametes via interspecies transplantation in salmonids. Cryobiology. 2016; 73: 286-290.

3. Ye H, Li CJ, Yue HM, Du H, Yang XG, Yoshino T, et al. Establishment of intraperitoneal germ cell transplantation for critically endangered Chinese sturgeon Acipenser sinensis. Theriogenology. 2017; 94: 37-47.

4. Yoshikawa H, Ino Y, Shigenaga K, Katayama T, Kuroyanagi M, Yoshiura Y. Production of tiger puffer Takifugu rubripes from cryopreserved testicular germ cells using surrogate broodstock technology. Aquaculture. 2018; 493: 302-313.

5. Higuchi K, Takeuchi Y, Miwa M, Yamamoto Y, Tsunemoto K, Yoshizaki G. Colonization, proliferation, and survival of intraperitoneally transplanted yellowtail Seriola quinqueradiata spermatogonia in nibe croaker Nibea mitsukurii recipient. Fisheries Sci. 2011; 77: 69-77.

6. Morita T, Morishima K, Miwa M, Kumakura N, Kudo S, Ichida K, et al. Functional Sperm of the Yellowtail (Seriola quinqueradiata) Were Produced in the Small-Bodied Surrogate, Jack Mackerel (Trachurus japonicus). Mar Biotechnol. 2015; 17: 644-54.

7. Okutsu T, Shikina S, Sakamoto T, Mochizuki M, Yoshizaki G. Successful production of functional $\mathrm{Y}$ eggs derived from spermatogonia transplanted into female recipients and subsequent production of $\mathrm{YY}$ supermales in rainbow trout, Oncorhynchus mykiss. Aquaculture. 2015; 446: 298-302.

8. Lin S, Long W, Chen J, Hopkins N. Production of germ-line chimeras in zebrafish by cell transplants from genetically pigmented to albino embryos. Proc Natl Acad Sci USA. 1992; 89: 4519-4523.

9. Takeuchi Y, Yoshizaki G, Takeuchi T. Biotechnology: surrogate broodstock produces salmonids. Nature. 2004; 430: 629.

10. Saito T, Goto-Kazeto R, Arai K, Yamaha E. Xenogenesis in teleost fish through generation of germ-line chimeras by single primordial germ cell transplantation. Biol Reprod. 2008; 78: 159-166.

11. Wong TT, Saito T, Crodian J, Collodi P. Zebrafish germline chimeras produced by transplantation of ovarian germ cells into sterile host larvae. Biol Reprod. 2011: 84: 1190-1197.

12. Yoshikawa H, Takeuchi Y, Ino Y, Wang J, Iwata G, Kabeya N, et al. Efficient production of donor-derived gametes from triploid recipients following intra-peritoneal germ cell transplantation into a marine teleost, Nibe croaker (Nibea mitsukurii). Aquaculture. 2016; 478: 35-47.

13. Takeuchi Y, Yoshizaki G, Takeuchi T. Generation of live fry from intraperitoneally transplanted primordial germ cells in rainbow trout. Biol Reprod. 2003; 69: 1142-1149.

14. Saito T, Goto-Kazeto R, Fujimoto T, Kawakami Y, Arai K, Yamaha E. Inter-species transplantation and migration of primordial germ cells in cyprinid fish. Int J Dev Biol. 2010; 54: 1481-1486.

15. Nóbrega RH, Greebe CD, van de Kant H, Bogerd J, de França LR, Schulz RW. Spermatogonial stem cell niche and spermatogonial stem cell transplantation in zebrafish. PLoS One. 2010; 5: e12808.

16. Li MY, Hong N, Xu HY, Song JX, Hong YH. Germline replacement by blastula cell transplantation in the fish medaka. Sci Rep. 2016; 6: 29658.

17. Seki S, Kusano K, Lee S, Iwasaki Y, Yagisawa M, Ishida M, et al. Production of the medaka derived from vitrified whole testes by germ cell transplantation. Sci Rep. 2017; 7: 43185

18. Hamasaki M, Takeuchi Y, Yazawa R, Yoshikawa S, Kadomura K, Yamada T, et al. Production of tiger puffer Takifugu rubripes offspring from triploid grass puffer Takifugu niphobles Parents. Mar Biotechnol. 2017; 19: 579-591.

19. Takeuchi Y, Higuchi K, Yatabe T, Miwa M, Yoshizaki G. Development of spermatogonial cell transplantation in Nibe croaker, Nibea mitsukurii (Perciformes, Sciaenidae). Biol Reprod. 2009; 81: 1055-1063.

20. Morita T, Kumakura N, Morishima K, Mitsuboshi T, Ishida M, Hara T, et al. Production of donor-derived offspring by allogeneic transplantation of spermatogonia in the yellowtail (Seriola quinqueradiata). Biol Reprod. 2012; $86: 176$

21. Lacerda SMSN, Costa GMJ, Campos-Junior PHA, Segatelli TM, Yazawa R, Takeuchi Y, et al. Germ cell transplantation as a potential biotechnological approach to fish reproduction. Fish Physiol Biochem. 2013; 39: 3-11.

22. Yoshizaki G, Yazawa R. Application of surrogate broodstock technology in aquaculture. Fisheries Sci. 2019; 85: 429-437.

23. Okutsu T, Suzuki K, Takeuchi Y, Takeuchi T, Yoshizaki G. Testicular germ cells can colonize sexually undifferentiated embryonic gonad and produce functional eggs in fish. Proc Natl Acad Sci USA. 2006; 103: 2725-2729.

24. Okutsu T, Shikina S, Kanno M, Takeuchi Y, Yoshizaki G. Production of trout offspring from triploid salmon parents. Science. 2007; 317: 1517.

25. Yoshizaki G, Ichikawa M, Hayashi M, Iwasaki Y, Miwa M, Shikina S, et al. Sexual plasticity of ovarian germ cells in rainbow trout. Development. 2010; 137: 1227-1230.
26. Yoshizaki G, Okutsu T, Ichikawa M, Hayashi M, Takeuchi Y. Sexual plasticity of rainbow trout germ cells. Anim Reprod Sci. 2010; 7: 187-196.

27. Yazawa R, Takeuchi Y, Higuchi K, Yatabe T, Kabeya N, Yoshizaki G. Chub mackerel gonads support colonization, survival, and proliferation of intraperitoneally transplanted xenogenic germ cells. Biol Reprod. 2010; 82: 896-904.

28. Bar I, Smith A, Bubner E, Yoshizaki G, Takeuchi $Y$, Yazawa $R$, et al Assessment of yellowtail kingfish (Seriola lalandi) as a surrogate host for the production of southern bluefin tuna (Thunnus maccoyii) seed via spermatogonial germ cell transplantation. Reprod Fertil Dev. 2016; 28: 2051-2064

29. Majhi SK, Hattori RS, Yokota M, Watanabe S, Strüssmann CA. Germ cell transplantation using sexually competent fish: an approach for rapid propagation of endangered and valuable germlines. PLoS One. 2009; 4: e6132.

30. Nóbrega RH, Batlouni SR, França LR. An overview of functional and stereological evaluation of spermatogenesis and germ cell transplantation in fish. Fish Physiol Biochem. 2009; 35: 197-206.

31. Takeuchi Y, Yazawa R, Yoshizaki G. Reproduction in Aquatic Animals. In: Chapter 17 Intraperitoneal Germ Cell Transplantation Technique in Marine Teleosts. Singapore: Springer Nature; 2020: 357-379.

32. Xu DD, Yoshino T, Konishi J, Yoshikawa H, Ino Y, Yazawa R, et al. 2019. Germ cell-less hybrid fish: ideal recipient for spermatogonial transplantation for the rapid production of donor-derived sperm. Biol Reprod. 2019; 101: 492-500.

33. Lee S, Iwasaki Y, Shikina S, Yoshizaki G. Generation of functional eggs and sperm from cryopreserved whole testes. Proc Natl Acad Sci USA. 2013; 110; 1640-1645.

34. Yoshizaki G, Takashiba K, Shimamori S, Fujinuma K, Shikina S, Okutsu T, et al. Production of germ cell-deficient salmonids by dead end gene knockdown, and their use as recipients for germ cell transplantation. Mol Reprod Dev. 2016; 83: 298-311.

35. Lacerda SMSN, Batlouni SR, Costa GMJ, Segatelli TM, Quirino BR, Queiroz $\mathrm{BM}$, et al. A new and fast technique to generate offspring after germ cells transplantation in adult fish: the Nile tilapia (Oreochromis niloticus) model. PLoS One. 2010; 5: e10740.

36. de Siqueira-Silva DH, Dos Santos Silva AP, da Silva Costa R, Senhorini JA, Ninhaus-Silveira A, Veríssimo-Silveira R. Preliminary study on testicular germ cell isolation and transplantation in an endangered endemic species Brycon orbignyanus (Characiformes: Characidae). Fish Physiol Biochem. 2021; 47: 767-776.

37. Piva LH, de Siqueira-Silva DH, Goes CAG, Fujimoto T, Saito T, Dragone LV, et al. Triploid or hybrid tetra: Which is the ideal sterile host for surrogate technology? Theriogenology. 2018; 108: 239-244.

38. Lei JL, Liu XF, Guan CT. Turbot culture in China for two decades: achievements and prospect. Progress in Fishery Sciences. 2012; 33: 123-130.

39. Xu DD, You F, Li J, Wu ZH, Xiao ZZ, Zhang PJ, et al. First evidence for hybrid breakdown in the backcross of olive flounder, paralichthys olivaceus, and summer flounder, paralichthys dentatus. J World Aquacult Soc. 2011; 42: 347-353.

40. Liu QH, Ma DY, Xu SH, Xiao ZZ, Xiao YS, Song ZC, et al. Summer flounder (Paralichthys dentatus) sperm cryopreservation and application in interspecific hybridization with olive flounder ( $P$ olivaceus). Theriogenology. 2015; 83: 703-710.

41. Pacchiarini T, Sarasquete C, Cabrita E. Development of interspecies testicular germ-cell transplantation in flatfish. Reprod Fertil Dev. 2014; 26: 690-702.

42. You F, Liu J. Karyotype evidences of triploidy in the left-eyed flounder, Paralichthys olivaceus (T. \& S.). Oceanol Limnol (Chineses Edition). 1995; 26 (Suppl 1): S115-S118

43. Bellaiche J, Lareyre JJ, Cauty C, Yano A, Allemand I, Le Gac F. Spermatogonial stem cell quest: nanos2, marker of a subpopulation of undifferentiated A spermatogonia in trout testis. Biol Reprod. 2014; 90: 79, 1-14.

44. Lacerda SMSN, Martinez ERM, Mura ILDD, Doretto LB, Costa GMJ, Silva MA, et al. Duration of spermatogenesis and identification of spermatogonial stem cell markers in a Neotropical catfish, Jundiá (Rhamdia quelen). Gen Comp Endocr. 2019; 273: 249-259.

45. Zhao CY, Liu QH, Xu SH, Xiao YS, Wang WQ, Yang JK, et al. Identification of type A spermatogonia in turbot (Scophthalmus maximus) using a new cell-surface marker of Lymphocyte antigen 75 (ly75/CD205). Theriogenology. 2018; 113: 137-145.

46. Dang W, Sun L. Determination of internal controls for quantitative real time RT-PCR analysis of the effect of Edwardsiella tarda infection on gene expression in turbot (Scophthalmus maximus). Fish Shellfish Immunol. 2011; 30: 720-728.

47. Yang Y, Liu QH, Xiao YS, Wang XY, An H, Song ZC, et al. Germ Cell Migration, Proliferation and Differentiation during Gonadal Morphogenesis in All-Female Japanese Flounder (Paralichthys Olivaceus). Anat Rec. 2018; 301: 727-741.

48. Majhi SK, Hattori RS, Rahman SM, Strüssmann CA. Surrogate production of eggs and sperm by intrapapillary transplantation of germ cells in cytoablated adult fish. PLoS One. 2014; 9: e95294.

49. Hattori RS, Yoshinaga TT, Katayama N, Hattori-Ihara S, Tsukamoto RY, Takahashi NS, et al. Surrogate production of Salmo salar oocytes and sperm in triploid Oncorhynchus mykiss by germ cell transplantation technology. Aquaculture. 2019; 506: 238-245.

50. Silva MA, Costa GMJ, Lacerda SMSN, Brandão-Dias PFP, Kalapothakis E, Silva Júnior AF, et al. Successful xenogeneic germ cell transplantation from 
Jundia catfish (Rhamdia quelen) into adult Nile tilapia (Oreochromis niloticus) testes. Gen Comp Endocr. 2016; 230-231: 48-56.

51. Farlora R, Hattori-Ihara S, Takeuchi Y, Hayashi M, Octavera A, Alimuddin, et al. Intraperitoneal germ cell transplantation in the Nile tilapia Oreochromis niloticus. Mar Biotechnol. 2014; 16: 309-320.

52. Shang M, Su B, Perera DA, Alsaqufi A, Lipke EA, Cek S, et al. Testicular germ line cell identification, isolation, and transplantation in two North American catfish species. Fish Physiol Biochem. 2018; 44: 717-733.

53. Sàbat M, Lo Nostro F, Casadevall M, Muñoz M. A light and electron microscopic study on the organization of the testis and the semicystic spermatogenesis of the genus Scorpaena (Teleostei, Scorpaenidae). J Morphol. 2009; 270: 662-672.

54. Mazzoldi C. Reproductive apparatus and mating system in two tropical goby species. J Fish Biol. 2001; 59: 1686-1691.

55. Biagi F, Piras F, Farina V, Zedda M, Mura E, Floris A, et al. Testis structure, spermatogenesis and sperm morphology in pipefishes of the genus Syngnathus. Acta Zool-stockholm. 2016; 97: 90-101. 